\title{
Status and potential distribution of the Asian carpenter bee, Xylocopa appendiculata Smith (Apidae, Xylocopini), in the United States
}

\author{
Allan H. Smith-Pardo', Glenn A. Fowler', Sunil Kumar² \\ I United States Department of Agriculture (USDA), Animal and Plant Health Inspection Service (APHIS), \\ Plant Protection and Quarantine (PPQ), Science and Technology (S\&T) 801 I Street, Suite 406, Sacramento, \\ California 95814, USA 2 United States Department of Agriculture (USDA), Animal and Plant Health In- \\ spection Service (APHIS), Plant Protection and Quarantine (PPQ), Science and Technology (S\&T) Raleigh, \\ North Carolina 27606, USA
}

Corresponding author: Allan H. Smith-Pardo (allan.h.smith-pardo@usda.gov)

Academic editor: Jack Neff | Received 18 December 2019 | Accepted 8 March 2020 | Published 27 April 2020

http://zoobank.org/84656D9D-D17C-483C-B697-4040173FECE1

Citation: Smith-Pardo AH, Fowler GA, Kumar S (2020) Status and potential distribution of the Asian carpenter bee, Xylocopa appendiculata Smith (Apidae, Xylocopini), in the United States. Journal of Hymenoptera Research 76: 99-111. https://doi.org/10.3897/jhr.76.49518

\begin{abstract}
We update the geographical distribution for Xylocopa appendiculata Smith, from eastern Asia, which was first reported from the United States of America (USA) in 2013. After the publication by Dahlberg et al. (2013), there have been more sightings supporting the establishment of $X$. appendiculata in northern California. We used plant hardiness zones and maximum entropy (Maxent) modeling to estimate the potential distribution of $X$. appendiculata in the USA using specimen data from multiple occurrences (confirmed data from literature, museum specimens and validated data from Discover Life.org and iNaturalist.org). We include images and a list of diagnostic features for the identification of the subgenus Alloxylocopa Hurd and Moure and the species X. appendiculata so that it can be identified and reported to corresponding state or federal authorities, if necessary.
\end{abstract}

\section{Resumen}

Se actualizan los datos de distribución de $X$. appendiculata Smith del este de Asia que fue reportada para los Estados Unidos de América por primera vez en 2013; después de este registro, se han presentado más avistamientos lo cual puede ser confirmación de que esta especie de hecho se ha establecido en el norte de California. Se utilizaron datos de "plant hardiness zones" (zonas de resistencias de plantas) y modelo de nichos Maxent para estimar la distribución potencial de esta especie en los EEUU mediante el uso de datos de especímenes de múltiples fuentes (datos confirmados de la literatura, ejemplares en museos

Copyright Allan H. Smith-Pardo et al. This is an open access article distributed under the terms of the Creative Commons Attribution License (CC BY 4.0), which permits unrestricted use, distribution, and reproduction in any medium, provided the original author and source are credited. 
y datos validados en Discover Life.org y iNaturalist.org) una distribución potencial de la especie en los EEUU con base en los datos de distribución original de la especie así como de datos en las bases de datos DiscoverLife.org y en la plataforma iNaturalist además de datos climáticos. Incluimos además imágenes y una lista de características diagnosticas del subgénero Alloxylocopa y de la especie X. appendiculata de manera que pueda ser identificada y reportada a las entidades federales o estatales en el futuro si es necesario.

\section{Keywords}

Biogeography, exotic bees, introduced species, invasive species, Maxent, Xylocopinae

\section{Palabras claves}

Biogeography, exotic bees, introduced species, invasive species, Maxent, Xylocopinae

\section{Introduction}

Bees of the genus Xylocopa Latreille are large and robust, 13-30 mm long (hence the common name of large carpenter bees), and are characterized, among other things, as having strongly sclerotized mouth parts (particularly the galeae), which are used to cut into corollas of tubular flowers to get the nectar (Sampson et al. 2004, Dedej and Delaplane 2004). Females of Xylocopa nest in wood, except those of subgenus Proxylocopa Hedicke which nest in the ground (Kronenberg and Hefetz 1984, Michener 2007).

Large carpenter bees have broad geographical distributions. They have diversified within tropical and subtropical regions and expanded their distributions to temperate regions (Hurd and Moure 1963). Several species of Xylocopa are suspected to have invaded oceanic islands, as only a few species exist within island groups and the distances between the original and their close relative's habitats are relatively short. For example, Xylocopa sonorina Smith was allegedly transferred by humans from North America to tropical Pacific islands, including Hawaii (Hurd 1958). More recently, Okabe et al. (2010) reported the introduction of the bamboo-nesting carpenter bee Xylocopa tranquebarorum (Swederus) in Japan. These authors also suspected that it was likely introduced from either India or China because of the characteristic mites associated with them. More recently, Dahlberg et al. (2013) reported Xylocopa appendiculata as introduced in California, United States.

Dahlberg et al. (2013) provided some diagnostic characteristics for the identification of $X$. appendiculata and some ways to separate it from native species in the USA. However, they used mostly coloration and the only picture in that paper is in black and white.

In this contribution, we provide information on the potential distribution of $X$. (Alloxylocopa) appendiculata in the USA. In addition, we include a diagnostic aid with images for the identification of the subgenus Alloxylocopa Hurd and Moure, and the species $X$. appendiculata and comments on its distribution, hosts, quarantine importance, and behavior. 


\section{Methods}

The specimen used for the images and identification aids was collected in San Jose, California in 2012 and cited by Dahlberg et al. (2013). We also received from Mrs. Dahlberg images of males visiting the same garden in two different years (see new records in the results section) and we used them for some of the information provided in the diagnostic aids of the species. The female specimen used in the aids is housed at the California State Collection of Arthropods in the California Department of Agriculture (CDFA) building in Meadowview, Sacramento, California. Images were taken using a Nikon SMZ18 dissection microscope with a Nikon Digital Sight ds-fi2 camera attached. Once a series of 15-20 images per view were taken, they were focus stacked using the program Helicon Focus (Heliconsoft) and edited using Adobe Photoshop CS6.

\section{Potential distribution modeling}

To predict areas where Xylocopa appendiculata could establish in the USA, we used location data for specimens at the American Museum of Natural History (AMNH, Jerome Rozen and Lance Jones), The Snow Entomological Collection at the University of Kansas Biodiversity and Natural History Museum (SEMC, Jennifer Thomas), and verified distribution data from iNaturalist (2019), Discover Life (2019), and the Global Biodiversity Information Facility (GBIF 2019) for specimens ID validated by taxonomists. For the iNaturalist data, we used research grade detections, which are identifications that over $2 / 3$ of the identifiers agree on (iNaturalist 2019). The combined dataset contained $325 \mathrm{X}$. appendiculata occurrences (duplicate records were removed). We also included in the analysis the type localities for $X$. appendiculata Smith, 1874 which is Ning-po-foo, China and X. appendiculata circumvolans (Smith, 1873) which is Hiogo, Japan (Appendix 1).

We used this dataset to predict where $X$. appendiculata could establish in the USA based on the associated Plant Hardiness Zones and Maxent niche modeling. We used two modeling approaches to increase the rigor of the analysis and better account for uncertainty regarding the bee's potential distribution in the USA.

The Plant Hardiness Zones are calculated based on the average annual extreme minimum temperature for an area in $10{ }^{\circ} \mathrm{F}\left(5.6^{\circ} \mathrm{C}\right)$ increments (ARS 2012). They can be used to predict where plant pests (e.g., insects) could establish based on the Plant Hardiness Zones that match with the pest's native range (PERAL 2013). We overlaid the $325 \mathrm{X}$. appendiculata occurrence points with a Plant Hardiness Zone layer that was based on average climate data from 1988 to 2017 (Takeuchi et al. 2018). We then mapped the corresponding plant hardiness zones in the United States to predict its distribution.

We used maximum entropy niche modeling (Maxent 3.3.3k; Phillips et al. 2006, 2017) to estimate the potential distribution of $X$. appendiculata in the United States. 
We removed duplicate records ( $>1$ presence point within a $\sim 4 \times 4 \mathrm{~km}$ grid cell) and reduced spatial autocorrelation using 'spatial filtering' (i.e. reducing density of occurrences) using SDMToolbox (Brown 2014; Kumar et al. 2016). The total occurrences from the native range (Japan, Korean peninsula, and China) and invaded range (California, USA) were reduced from 325 to 158 (Appendix 1). We then calculated a Gaussian Kernel Density layer of occurrence data in ArcMap using SDMToolbox, which we used to account for potential sampling bias in occurrence data. We obtained climatic data from CHELSA website (Climatologies at High resolution for the Earth's Land Surface Areas; http://chelsa-climate.org/; Karger et al. 2017). We downloaded 19 bioclimatic variables data layers $(-4 \times 4 \mathrm{~km}$ spatial resolution) which represent average monthly temperature, precipitation, seasonal variables, and climatic extreme indices data from 1979-2013 (Hijmans et al. 2005; Appendix 2). We examined all 19 variables for cross-correlation (Pearson correlation coefficient, $\mathrm{r}$ ) and highly correlated variables $(|r|>0.80)$ were excluded to reduce multicollinearity. The decision to exclude or include a variable was based on its potential biological relevance to $X$. appendiculata and its relative predictive power in the model (Appendix 2,3).

Multiple models were fitted with different feature types and regularization multiplier values, and the best model with the optimal level of complexity was selected. Performance of the model was evaluated using the area under the receiver operating characteristic (ROC) curve (AUC; Peterson et al. 2011). We used the 10-fold cross-validation procedure for evaluating model performance, and reported averaged test AUC values across the ten replicates. Unsuitable areas for $X$. appendiculata were defined using the 100 percent sensitivity threshold (Liu et al. 2013). Therefore, areas with $>0.107$ probability of presence in Maxent modeling results were considered as suitable for $X$. appendiculata.

\section{Results}

\section{Potential distribution of $X$. appendiculata in the USA}

The analysis of potential U.S. areas for Xylocopa appendiculata establishment based on plant hardiness zones (Figure 1) predicted that $X$. appendiculata could establish in Plant Hardiness Zones 5 to 10. This area includes most of the contiguous United States, and parts of southern and coastal Alaska (Figure 1). Colder regions like North Dakota, most of Alaska and the Rocky Mountains, and warmer regions like southern Florida and Hawaii were predicted to be unsuitable. Xylocopa appendiculata's predicted cold hardiness is due to it's occurrence in colder parts of Japan.

The plant hardiness zone model likely represents a worst case scenario for $X$. appendiculata's potential U.S. distribution due to the coarseness of the approach. This conclusion is supported by the fact that no western species of Xylocopa reach Canada, except for $X$. virginica which is present in the most southern parts of Ontario and Quebec. 


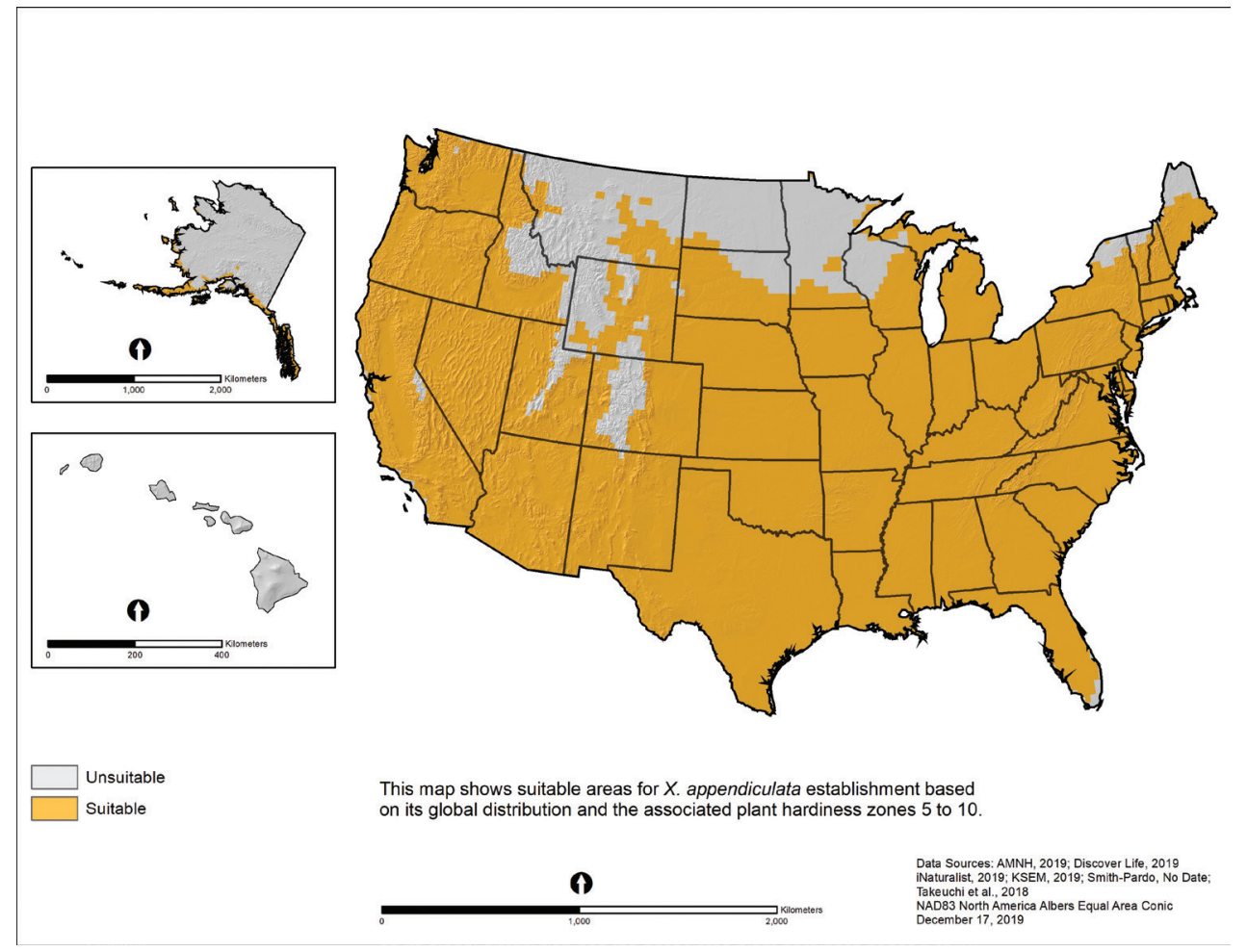

Figure I. Suitable U.S. areas for Xylocopa appendiculata establishment based on plant hardiness zones This map shows suitable areas for $X$. appendiculata establishment based on its global distribution and the associated plant hardiness zones 5 to 10 .

The second analysis, or Maxent model, predicted climatically suitable areas for $X$. appendiculata in the eastern United States, parts of California, southwestern Alaska, and parts of Hawaii (Figure 2). Our model indicated medium to low climatic suitability (probability between $0.40-0.10$ ) in parts of California, and very low suitability in Hawaii (probability 0.10-2.0) (Figure 2). The Maxent model for X. appendiculata performed well with a test AUC value of 0.98 (an AUC value of 1.0 indicates superior performance, and 0.5 indicates performance no better than random; Peterson et al. 2011). Precipitation of warmest quarter (Bio18) and temperature seasonality (Bio4) were the two top predictors associated $X$. appendiculata's distribution, with $45 \%$ and $28 \%$ contributions, respectively (Appendix 2).

The climatic response curves fitted by the Maxent model suggest that areas with average annual temperatures (Bio1) between $4{ }^{\circ} \mathrm{C}$ and $22{ }^{\circ} \mathrm{C}$, and average annual precipitation (Bio12) between $200 \mathrm{~mm}$ and $3,800 \mathrm{~mm}$ are likely suitable for $X$. appendiculata (Appendix 3). The distinct contrast in the patterns in predicted climatic suitability for $X$. appendiculata in northeastern Texas, Arkansas, northern Louisiana, western Mississippi and Tennessee, is probably due to variation in average summer 

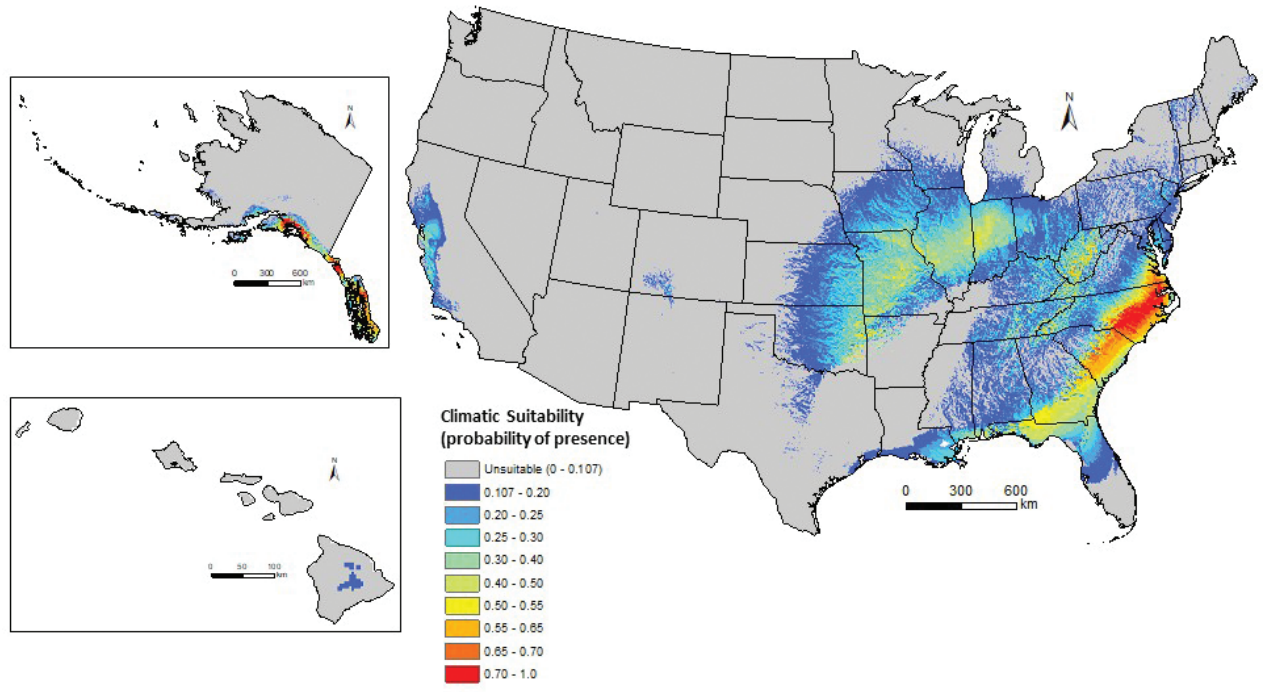

This map visualizes the predicted climatic suitability (probability of presence) for Xylocopa appendiculata in the United States. The global occurrence data (triangles) were integrated with climatic data using Maxent ecological niche model to produce probability of presence.
Sources: ESRI, No Date; Karger et al. (2017); AMNH, 2019; Discover Life, 2019; iNaturalist, 2019; KSEM, 2019; Smith-Pardo, No Date NAD83 Albers Equal Area Conic December 17, 2019

Figure 2. Predicted climatic suitability for Xylocopa appendiculata in the United States.

precipitation (June, July and August) in that part of the country (Appendix 4). Based on where the plant hardiness zone and Maxent models agree, the areas at greatest risk for $X$. appendiculata establishment include parts of southern Alaska and portions of eastern Virginia and the Carolinas (Figures 1,2). Other at-risk areas include portions of western California and the eastern, north central, and central United States.

\section{New observations and distribution records}

\section{USA records}

USA. 1 ; ; California: San Jose; Sept. 2012; on flowers of Salvia azurea Michx. ex Lam. (Lamiaceae).1 §ं; same locality data; May 2013; on flowers of Erysimum linifolium (Pers.) J. Gay (Brassicaceae). 2§; same locality data; Apr. 2015; on flowers Erysimum linifolium (Brassicaceae). 1; same locality data; Mar.2017; on flowers of Prunus cerasifera Ehrh (Rosaceae). 1q; same locality data; May 2019; on flowers Erysimum linifolium (Brassicaceae).

USA. 19; California: Castro Valley; 37²2'13"N, 12203'35"W; Sept. 2017; on flowers of Grewia occidentalis L. (Malvaceae). 19; same locality data; Aug. 2018; on flowers of Passiflora sp. L. (Passifloraceae). These two records show the movement of the species further north ( $-32-45$ kilometers $)$ from where the species was first reported in northern California. 


\section{Diagnostic aid for the identification of Xylocopa appendiculata}

Bees of the subgenus Alloxylocopa Hurd and Moure (before the introduction of X. appendiculata, the subgenus was not known to be present in the Western hemisphere) can be distinguished from all other Xylocopa subgenera that are present in the USA and Canada by the following combination of characters: (female) pygidial plate without subapical spines (Fig. 3d, pp: pygidial plate), (both sexes) mesoscutellum with sub-horizontal dorsal surface abruptly and angulately separated from sub-vertical surface (Fig. 3e), postero-dorsal margin of mesoscutellum not surpassing posterior margin of metanotum and not projecting posteriorly beyond its posterior surface as a thin-edged flange., vertical fold of metasomal tergum 1 with foveate, hollow-like depression (Fig. 3f, arrow),

Specimens of $X$. appendiculata can be distinguished from native U.S. species of carpenter bees by the following combination of features: mandible with two teeth (Fig. $3 \mathrm{~g}$, arrow); clypeus and paraocular areas strongly punctate (Fig. 3b, square); occipital area, mesosoma and external side of fore tibiae with pubescence bright yellow, black on most of metasoma (Fig. 3a), except for few light brown setae close to pygidial plate

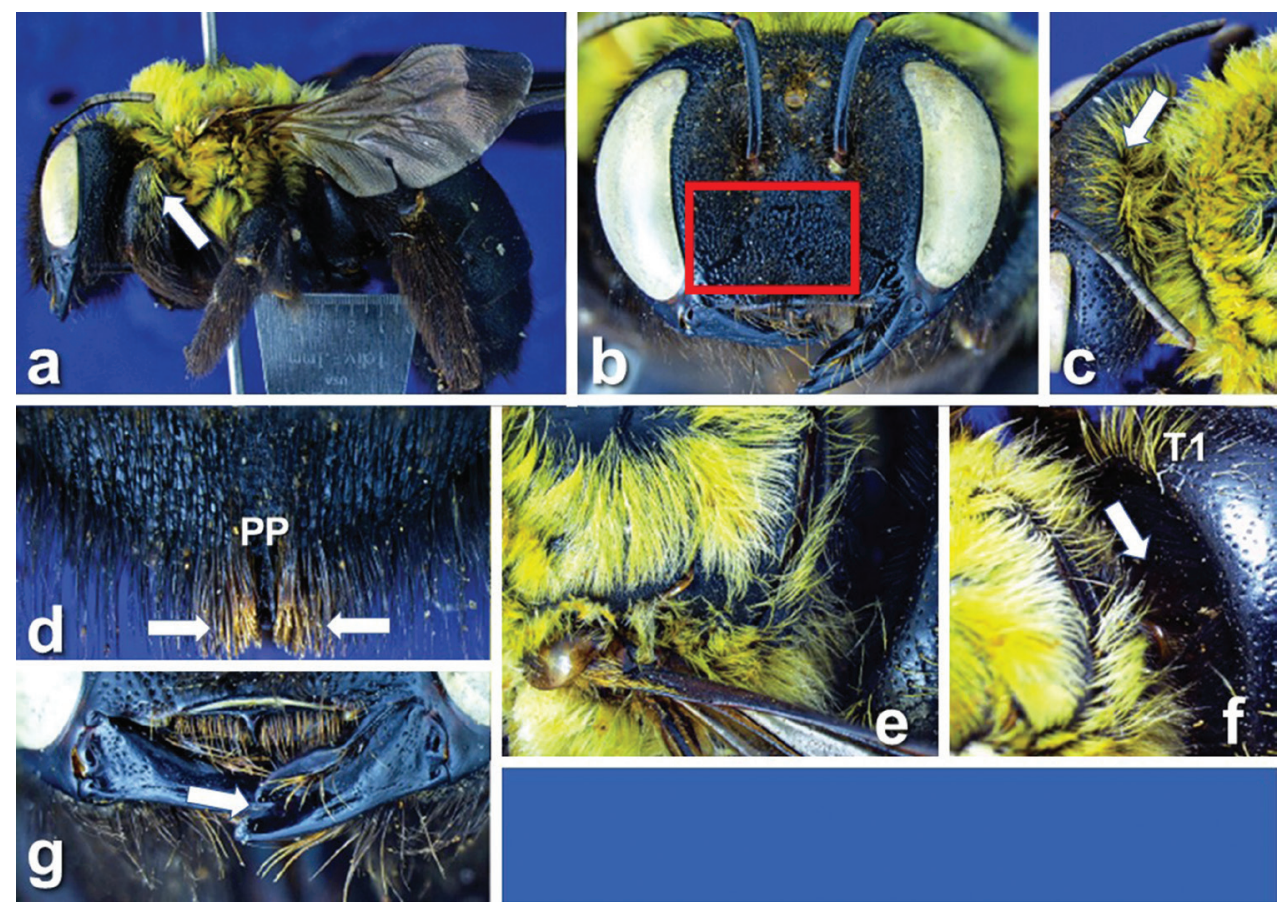

Figure 3. Some of the diagnostic features of Xylocopa appendiculata Smith: a lateral habitus showing coloration of pubescence on mesosoma and metasoma (the yellow coloration may not be as fluorescent in field specimens and is mostly due to reflections from the imaging system) $\mathbf{b}$ face showing integument sculpturing of clypeus and paraocular area c coloration of pubescence around occipital area (arrow) $\mathbf{d}$ pygidial plate (pp) and coloration of pubescence close to it (arrows) e shape of mesoscutellum from lateral view $\mathbf{f}$ Shape of metasomal tergum 1 (T1) from antero-lateral view and the presence of a foveate, hollowed like depression (arrow) $\mathbf{g}$ dentation of mandibles (arrow showing the two teeth on mandible). 
on female (Fig. 3d, arrows); (Fig. 3c, arrow), Fig. 3a, e) and (Fig. 3a, arrow). The mesosoma of the native, North American species can be covered with black, grayish, brownish, or pale yellow setae and often have pale hairs elsewhere on the body and/or metallic highlights on the integument (Hurd and Moure 1963). The most similar of the native carpenter bees in the U.S. is Xylocopa virginica L. (the Eastern carpenter bee) which also has two mandibular teeth and a strongly punctuate clypeus, but differs from $X$. appendiculata because it lacks the extensive bright yellow hairs in the mesosoma and vertex. The males of $X$. appendiculata also lack the extensive bluish or greenish reflections of the body present in males of $X$. virginica.

\section{Floral hosts}

Little is known about the preferred plants visited and pollinated by $X$. appendiculata in its native range, but based on the observations of visits in the USA this species seems, at least potentially, polylectic in its floral preferences. In the new habitat in the Bay Area this species was seen visiting flowers of introduced plants such as Grewia occidentalis (originally from Africa) and Passiflora sp. (originally from tropical America). Both plants were in the senior author's bee garden in Castro Valley, CA.

\section{Discussion}

Dahlberg et al. (2013) provided a list of all the U.S. species of Xylocopa and their distributions by the state. The potential distribution maps show that $X$. appendiculata could establish in all the states where native species of carpenter bees occur according to the distribution records in literature. This is especially true in the east coast where it could broadly overlap with the common species $X$. virginica. Due to their morphological similarities successful diagnosis would require careful examination and the use of the diagnostic aids provided here.

As with all new introduced species, there is a risk that $X$. appendiculata will be better at competing for foraging plants and nesting sites (dry or rotten wood), which may limit resources for native bees. In addition, carpenter bees can be a nuisance because they can nest in human made structures such as fences and roofs. Due to their large size, females of $X$. appendiculata can also damage flowers while feeding without pollinating them.

There is evidence of introduced carpenter bees bringing new parasites (and possibly diseases) to invaded areas (Okabe et al. 2010; Kontschán et al. 2016). There may be new parasites associated with this species that do not occur in the USA that can be potentially damaging to our native Xylocopa species.

As is the case with other wood nesting bees that have been introduced into the USA, $X$ appendiculata will likely compete with native species for empty nesting sites or even usurp them when sites are limited (Mangum and Brooks 1997; Batra 1998; Laport and Minckley 2012). 
In addition, Xylocopa appendiculata also nests in wood, twigs and large stalks of dead plants commonly used to make shipping crates and woodcrafts, which could increase its rate of spread over long distances and across natural barriers such as oceans and mountain ranges.

Given $X$. appendiculata's potential to establish in the United States and outcompete native carpenter bees it is important to continue monitoring its spread. In this regard, our analysis can assist with $X$. appendiculata identification and informing surveys.

\section{Acknowledgements}

We thank Dr. Martin Hauser from CDFA in Sacramento for lending us the original specimen of $X$. appendiculata collected in San Jose for this study. We thank the museum curators and curatorial assistants, listed under methods, for providing us the distribution data for specimens in their collections. We also thank Mr. Timothy Torbett, Botanist with the USDA-APHIS in South San Francisco, for his identifications of the plants visited by the species in Castro Valley. This is a contribution of Science and Technology, Center for Plant Health Science and Technology (CPHST- S\&T) of the United States Department of Agriculture, Animal and Plant Health Inspection Service, Plant Protection and quarantine (USDA-APHIS-PPQ).

\section{References}

ARS (2012) USDA Plant Hardiness Zone Map. United States Department of Agriculture, Agricultural Research Service (ARS). Last accessed April 30, 2019, https://planthardiness.ars.usda.gov Batra SWT (1998) Biology of the giant resin bee, Megachile sculpturalis Smith, a conspicuous new immigrant in Maryland. Maryland Naturalist 42: 1-3.

Brown JL (2014) SDMtoolbox: a python-based GIS toolkit for landscape genetic, biogeographic and species distribution model analyses. Methods in Ecology and Evolution 5(7): 694-700. https://doi.org/10.1111/2041-210X.12200

Dahlberg L, Hauser M, Yanega D (2013) Japanese carpenter bee, Xylocopa appendiculata Smith 1852 (Hymenoptera: Apidae) potentially established in Santa Clara County, first record for North America. Pan Pacific Entomologist 89(4): 226-229. https://doi.org/10.3956/2013-22.1

Dedej S, Delaplane KS (2004) Nectar-Robbing Carpenter Bees Reduce Seed-Setting Capability of Honey Bees (Hymenoptera: Apidae) in Rabbit eye Blueberry, Vaccinium ashei, 'Climax. Environmental Entomology 33(1): 100-106. https://doi.org/10.1603/0046-225X-33.1.100

Discover Life (2019) https://www.discoverlife.org/ [Accessed October 2019]

GBIF (2019) Global Biodiversity Information Facility (GBIF). GBIF Secretariat. https://www. gbif.org/ [Accessed October 2019]

Hijmans RJ, Cameron SE, Parra JL, Jones PG, Jarvis A (2005) Very high resolution interpolated climate surfaces for global land areas. International Journal of Climatology 25(15): 1965-1978. https://doi.org/10.1002/joc.1276 
Hurd PD, Moure JS (1963) A classification of the large carpenter bees (Xylocopini) (Hymenoptera: Apoidea). University of California Publications in Entomology 29: 1-365.

Hurd PD (1958) The carpenter bees of the eastern pacific oceanic islands. Journal of the Kansas Entomological Society 31: 249-255.

iNaturalist (2019) https://www.inaturalist.org/ [Accessed October 2019]

Karger DN, Conrad O, Böhner J, Kawohl T, Kreft H, Soria-Auza RW, Zimmermann NE, Linder HP, Kessler M (2017) Climatologies at high resolution for the earth's land surface areas. Scientific Data 4: 170-122. https://doi.org/10.1038/sdata.2017.122

Keasar T (2010) Large Carpenter Bees as Agricultural Pollinators. Psyche 2010 (927463): 7 pp. https://doi.org/10.1155/2010/927463

Kontschán J, Jeon MJ, Hwang JM, Seo HY (2016) First record of four bee (Hymenoptera: Apidae) associated mite species (Acari) from Democratic People's Republic of Korea. Journal of Species Research 5 (1): 27-30. https://doi.org/10.12651/JSR.2016.5.1.027

Kronenberg S, Hefetz A (1984) Comparative analysis of Dufour's gland secretions of two carpenter bees (Xylocopinae: Anthophoridae) with different nesting habits. Comparative Biochemistry and Physiology, B, Comparative Biochemistry 79(3): 421-425. https://doi. org/10.1016/0305-0491(84)90399-7

Kumar S, Yee WL, Neven LG (2016) Mapping global potential risk of establishment of Rhagoletis pomonella (Diptera: Tephritidae) using MaxEnt and CLIMEX niche models. Journal of Economic Entomology 109(5): 2043-2053. https://doi.org/10.1093/jee/tow166

Laport RG, Minckley RL (2012) Occupation of active Xylocopa virginica nests by the recently invasive Megachile sculpturalis in Upstate New York. Journal of the Kansas Entomological Society 85(4): 384-386. https://doi.org/10.2317/0022-8567-85.4.384

Liu C, White M, Newell G (2013) Selecting thresholds for the prediction of species occurrence with presence-only data. Journal of Biogeography 40: 778-789. https://doi.org/10.1111/jbi.12058

Mangum WA, Brooks RW (1997) First records of Megachile (Callomegachile) sculpturalis Smith (Hymenoptera: Megachilidae) in the continental United States. Journal of the Kansas Entomological Society 70: 146-148.

Michener CD (2007) The Bees of the World ( $2^{\text {nd }}$ ed.) Johns Hopkins University Press, Baltimore and London, $953 \mathrm{pp}$.

Okabe K, Masuya H, Kawazoe K, Makino S (2010) Invasion pathway and potential risks of a bamboo-nesting carpenter bee, Xylocopa tranquebarorum (Hymenoptera: Apidae), and its micro-associated mite introduced into Japan. Applied Entomology and Zoology 45(2): 329-337. https://doi.org/10.1303/aez.2010.329

PERAL (2013) Guidelines for Plant Pest Risk Assessment of Imported Fruit \& Vegetable Commodities (08/2012-01). United States Department of Agriculture, Animal and Plant Health Inspection Service, Plant Protection and Quarantine, Center for Plant Health Science and Technology, Plant Epidemiology and Risk Analysis Laboratory (PERAL), Raleigh, NC. 142 pp. 
Peterson AT, Soberon J, Pearson RG, Anderson RP, Martinez-Meyer E, Nakamura M, Araujo MB (2011) Ecological niches and geographic distributions. Princeton University Press, Princeton, N.J. https://doi.org/10.23943/princeton/9780691136868.003.0003

Phillips SJ, Anderson RP, Schapire RE (2006) Maximum entropy modeling of species geographic distributions. Ecological Modelling 190(3-4): 231-259. https://doi.org/10.1016/j.ecolmodel.2005.03.026

Phillips SJ, Anderson RP, Dudik M, Schapire RE, Blair ME (2017) Opening the black box: An open-source release of Maxent. Ecography 40(7): 887-893. https://doi.org/10.1111/ ecog.03049

Sadeh A, Shmida A, Keasar T (2007) The Carpenter Bee Xylocopa pubescens as an Agricultural Pollinator in Greenhouses. Apidologie: 508-517. https://doi.org/10.1051/apido:2007036 SAFARIS (2019) Spatial Analytic Framework for Advanced Risk Information Systems (SAFARIS). United States Department of Agriculture (USDA) and North Carolina State University (NCSU). https://safaris.cipm.info/safarispestmodel/StartupServlet?safarishome

Sampson BJ, Danka RG, Stringer SJ (2004) Nectar Robbery by Bees Xylocopa virginica and Apis mellifera Contributes to the Pollination of Rabbit eye Blueberry. Journal of Economic Entomology 97(3): 735-740. https://doi.org/10.1603/0022-0493(2004)097[0735:NRB BXV]2.0.CO;2

Smith F (1852) VIII. Descriptions of some new and apparently undescribed species of Hymenopterous Insects from North China, collected by Robert Fortune, Esq. Transactions of the Entomological Society of London, New Series v. ii, Vol. 7: 33-44. https://doi. org/10.1111/j.1365-2311.1852.tb02208.x

Smith F (1873) VIII. Descriptions of Aculeate Hymenoptera of Japan, collected by Mr. George Lewisat Nagasaki and Hiogo. Transactions of the Entomological Society of London, Vol. 21: 181-206. https://doi.org/10.1111/j.1365-2311.1873.tb00641.x

Smith-Pardo A (constantly updating) Xylocopa appendiculata occurrence (personal observation). United States Department of Agriculture, Animal and Plant Health Inspection Service, Plant Protection and Quarantine, Science and Technology, Sacramento, CA.

Solomon-Raju AJ, Purnachandra-Rao S (2006) Nesting habits, floral resources and foraging ecology of large carpenter bees (Xylocopa latipes and Xylocopa pubescens) in India. Current Science 90(9): 1210-1217.

Sugiura N (1995) Burrow construction by the Japanese carpenter bee, Xylocopa appendiculata circumvolans Smith, for overwintering (Hymenoptera: Anthophoridae). Journal of the Kansas Entomological Society 68(1): 116-119.

Takeuchi Y, Fowler G, Joseph AS (2018) SAFARIS: Global Plant Hardiness Zone Development. North Carolina State University, Center for Integrated Pest Management; United States Department of Agriculture, Animal and Plant Health Inspection Service, Plant Protection and Quarantine, Science and Technology, Plant Epidemiology and Risk Analysis Laboratory, Raleigh, NC. 6 pp. 


\section{Appendix I}

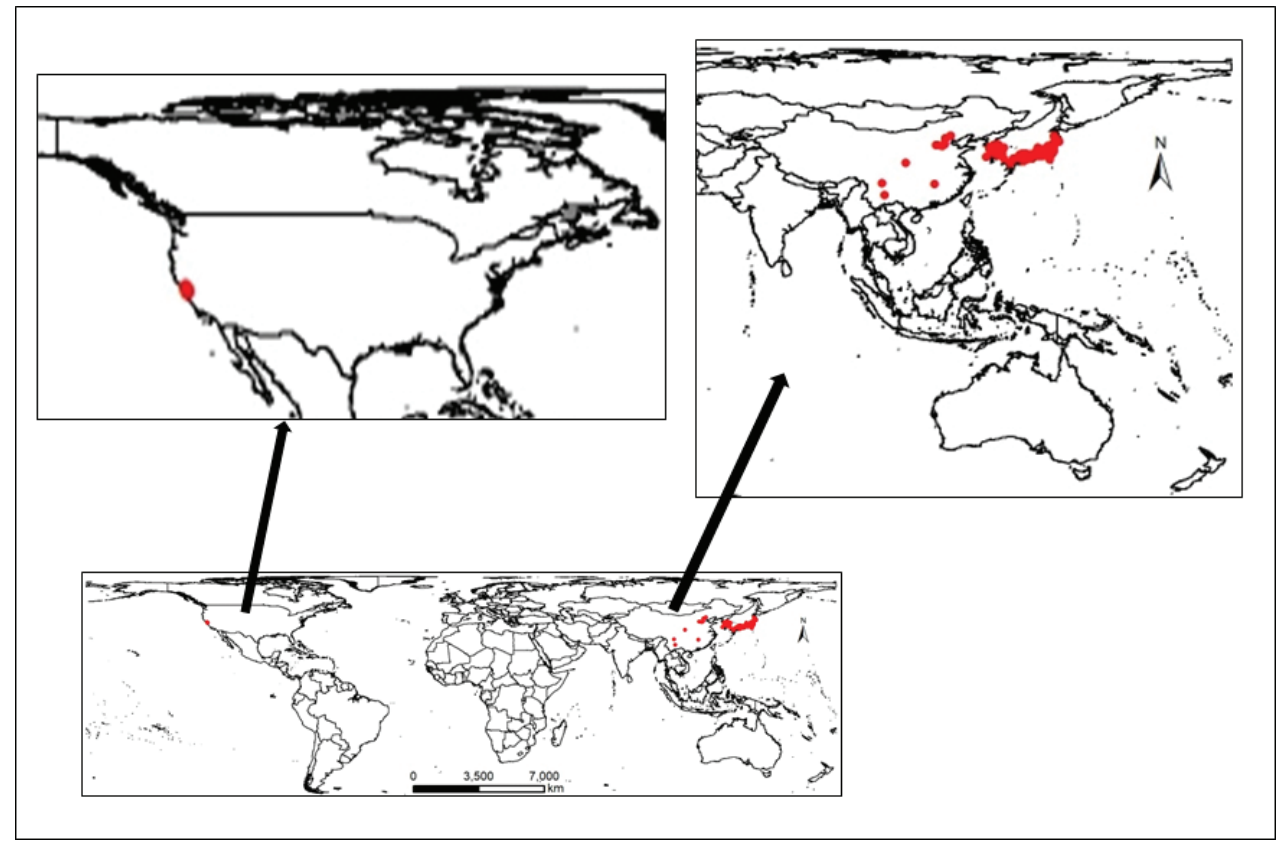

Figure AI. Global distribution of Xylocopa appendiculata based on specimens deposited in collections and confirmed records on iNaturalist, GBIF, and Discover Life.org (red circles).

\section{Appendix 2}

Table A I. Relative importance of 19 climatic variables considered in Xylocopa appendiculata Maxent model. Bold shows the variables used in the Maxent model; other variables were dropped because of high crosscorrelations or lower predictive power in the model. Presented values are averages for 10 replicate runs.

\begin{tabular}{|c|c|}
\hline Variable & Percent contribution \\
\hline Precipitation of warmest quarter (Bio18; mm) & 45.3 \\
\hline Temperature seasonality (SD x 100) (Bio4) & 27.9 \\
\hline Mean annual precipitation (Bio12; mm) & 15.0 \\
\hline Mean temperature of driest quarter $\left(\mathrm{Bio} 9{ }^{\circ}{ }^{\circ} \mathrm{C}\right)$ & 6.0 \\
\hline Precipitation of driest month (Bio14; mm) & 4.5 \\
\hline Precipitation seasonality (CV) (Bio15) & 1.2 \\
\hline Annual mean temperature $\left(\mathrm{Bio} 1 ;{ }^{\circ} \mathrm{C}\right)$ & - \\
\hline Mean diurnal range in temperature $\left(\mathrm{Bio} 2 ;{ }^{\circ} \mathrm{C}\right)$ & - \\
\hline Isothermality (Bio3) & - \\
\hline Maximum temperature of warmest month $\left(\mathrm{Bio} 5 ;{ }^{\circ} \mathrm{C}\right)$ & - \\
\hline Minimum temperature of coldest month $\left(\mathrm{Bio} 6 ;{ }^{\circ} \mathrm{C}\right)$ & - \\
\hline Temperature annual range $\left(\mathrm{Bio} 7{ }^{\circ} \mathrm{C}\right)$ & - \\
\hline Mean temperature of wettest quarter $\left(\mathrm{Bio} 8 ;{ }^{\circ} \mathrm{C}\right)$ & - \\
\hline Mean temperature of warmest quarter $\left(\mathrm{Bio} 10 ;{ }^{\circ} \mathrm{C}\right)$ & - \\
\hline Mean temperature of coldest quarter $\left(\mathrm{Bio} 11 ;{ }^{\circ} \mathrm{C}\right)$ & - \\
\hline Precipitation of wettest month (Bio13; mm) & - \\
\hline Precipitation of wettest quarter (Bio $16 ; \mathrm{mm}$ ) & - \\
\hline Precipitation of driest quarter (Bio17; mm) & - \\
\hline Precipitation of coldest quarter (Bio19; mm) & - \\
\hline
\end{tabular}




\section{Appendix 3}

Table A2. Pearson correlation (r) among the six best predictors in the Xylocopa appendiculata Maxent model; see Appendix1 for variable names.

\begin{tabular}{lccccc}
\hline & Bio4 & Bio9 & Bio12 & Bio14 & Bio15 \\
\hline Bio9 & -0.787 & & & & \\
Bio12 & -0.568 & 0.289 & & & \\
Bio14 & -0.265 & 0.085 & 0.732 & & \\
Bio15 & -0.133 & 0.254 & -0.298 & -0.527 & \\
Bio18 & -0.241 & -0.030 & 0.727 & 0.593 & -0.273 \\
\hline
\end{tabular}

\section{Appendix 4}
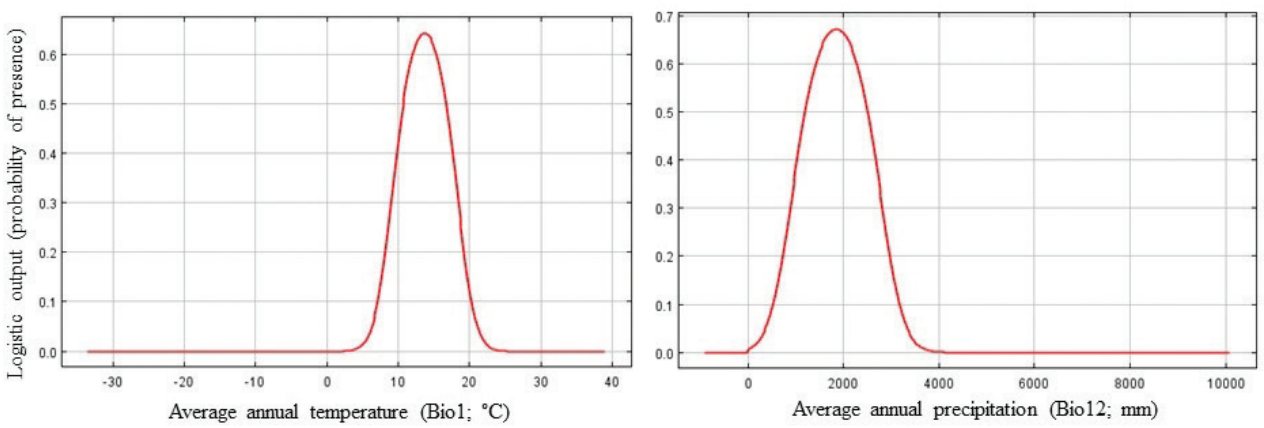

Figure A2. Climatic variables' response curves fitted by Maxent model for Xylocopa appendiculata.

\section{Appendix 5}

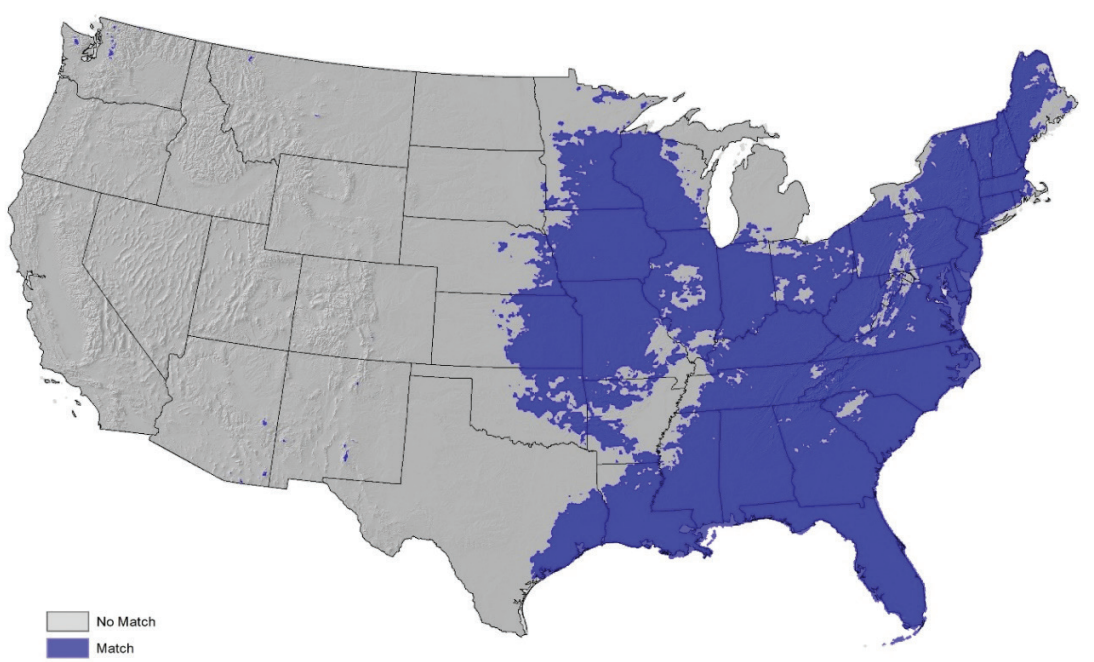

Figure A3. Summer Precipitation Patterns in the USA: Average summer precipitation (June, July and August) was calculated using PRISM climate data with the Spatial Analytic Framework for Advanced Risk Information Systems (SAFARIS 2019). Areas with $\geq 300 \mathrm{~mm}$ of precipitation between June and August (blue) based on average data from 2000 to 2019. 